\title{
Identification of Potential for Increasing the Business Scale of BUMG Pulo Makmue with the AHP Method
}

\author{
Muhammad Zakaria $^{1 *}$, Saifuddin Muhammad Jalii ${ }^{2}$, Trisna $^{1}$, Zuraida $^{1}$ \\ ${ }^{1}$ Department of Industrial Engineering, Universitas Malikussaleh, Aceh, Indonesia \\ ${ }^{2}$ Department of Electrical Engineering, Universitas Malikussaleh, Aceh, Indonesia \\ *Corresponding authorE-mail: irmuhammad@unimal.ac.id
}

Manuscript received 15 Nov 2021; revised 20 Nov 2021; accepted 1 Jan 2022. Date of publication 10 Jan 2022

\begin{abstract}
The village is the lowest regional unit in the state administrative apparatus in Indonesia, where the village is currently entering a new era after the birth of the Village Law. Village are expected to become socially, culturally, economically, and politically independent. Village Owned Enterprises (BUMDes) as business and economic institutions is expected to welcome the village community to be more independent, especially in economy. Currently BMUG Pulo Makmue is still facing various obstacles in carrying out its operations, especially in determining business strategies to increase business scale based on priority scales. This study aims to determine the policy priorities that can be taken as a business strategy to increase the Business Scale of BMUG Ulee Makmue. With the increase in business scale, BMUG Pulo Makmue will become an independent and advanced BMUG so that it can meet the expectations of the people of Ulee Pulo Village in terms of improving their welfare. The research was conducted by conducting surveys and collecting data directly in the field while still applying the Covid 19 process. The research method used was the Analytical Hierarchy Process (AHP) analysis to determine the potential for developing study BUMDes in Ulee Pulo Village. The expected result in this study is the potential of Gampong that can be developed by considering the available resources based on a priority scale. To determine alternative priorities in developing the potential of Ulee Pulo Village in the context of developing Ulee Pulo BUMG, it is determined by distributing questionnaires to determine the criteria and level of importance of each potential. The criteria assessed are long-term prospects, working capital, and income.
\end{abstract}

Keywords: Potential Resources, Pulo Makmue BMUG, AHP, Gampong Development.

\section{Introduction}

Some of the things that become a fundamental problem for BUMDes in general are the limited human resources in managing the business units contained within the BUMDes itself. The lack of production management innovation for BUMDes whose business units are in the field of Production and tourism is a separate problem. The products produced by BUMDes have not been able to compete with factorymade production, and the ability to explore the local potential of the village and business planning is still lacking [1] [2]. The driving factors for village development include the many potentials that the village has, such as economic potential and environmental potential. In addition, the carrying capacity of the village community and village government is also very important for village progress. Meanwhile, what can hinder village development is a conflict of interest between the community and the village government which can result in village development programs being neglected or failing[3]-[9].

Pulo Makmue BMUG in Ulee Pulo Village, Dewantara District, North Aceh Regency is one of the relatively new BUMDes established in 2019 based on the Gampong Ulee Pulo Qanun Number 02 of 2019 [10]. Based on this, the existence of BUMDes is an important consideration for channeling village community initiatives in developing village potential ,managing and utilizing the potential of village natural resources, optimizing human resources (village residents) in their management, and the existence of capital participation from the village government in the form of village financing and assets that are submitted to be managed as part of BUMDes [11]. Through the development of village potential accompanied by community participation in managing BUMDes, it will encourage the village economy and create village economic independence[12]-[14] [15].

\section{Literature Review}

\subsection{Village Owned Enterprises (BUMDes)}

BUMDes is a business entity established through a Village Regulation based on the results of the Village Deliberation, based on a Village Regulation, and does not require ratification from a Notary Deed. However, based on Article 7 of Law Number 6 of 2014 concerning Villages, BUM Desa can consist of business units that are legal entities such as Limited Liability Companies (PT) and Micro Finance Institutions (LKM) [11] [16]. The legal basis for BUMDes includes Law Number 6 of 2014 concerning Villages; Government Regulation Number 43 of 2014 concerning Implementing Regulations of Law Number 6 of 2014 concerning Villages; Government Regulation Number 47 of 2015 concerning Amendments to the Implementing Regulations of Law Number 6 of 2014 concerning Villages; and Regulation of 
the Minister of Villages, Development of Disadvantaged Regions, and Transmigration Number 4 of 2015 concerning the Establishment, Management and Management, and Dissolution of Village-Owned Enterprises. The objectives of BUMDes include improving the village economy, optimizing village assets to benefit the welfare of the village, increasing community efforts in managing the economic potential of the village to create employment opportunities, improving community welfare through improving public services, growth, and income distribution. village economy; and increase village community income and Village Original Income. Village Capital Participation, consisting of grants from the private sector, community socio-economic institutions and/or donor agencies, Government assistance through the Village APB mechanism, Village Assets submitted to the Village APB in accordance with the provisions of the legislation on Village Assets[17]-[19] [20].

\subsection{Process Analytical Hierarchy (AHP)}

The Analytical Hierarchy Process (AHP) method is an analytical method developed by Thomas L. Saaty in the 1970s. This method can be used to structure problems and make decisions about alternatives. In its development, AHP is not only used to determine priority choices with many criteria, but its application has penetrated into various alternative models, such as cost-benefit analysis, portfolio selection, forecasting, and others. This method is one of the multi-criteria decision-making models that can help the human frame of mind where the factors of logic, experience, knowledge, emotions, and feelings are optimized into a systematic process [21]-[24] [25].

Basically AHP is a method used to solve complex and unstructured problems into groups, by arranging the groups into a hierarchy, then entering numeric values as a substitute for human perception in making relative comparisons. Synthesis will be able to determine which element has the highest priority.

\subsection{Prioritize each element.}

This priority is generated from a pairwise comparison matrix between all elements at the same hierarchical level[26]. Each element/criteria contained in the hierarchy must be weighed relative to each other. The aim is to determine the level of interest/preference of the parties concerned in the matter. The first step in determining the priority of the arrangement of elements is to make pairwise comparisons, which is to compare all elements in pairs for each hierarchical subsystem. The comparison is then converted into a matrix for numerical analysis purposes. An example of a comparison matrix is stated in table 1 below:

Table 1. Pairwise comparison matrix

\begin{tabular}{llllll}
\hline B & 1 & 2 & 3 &.. & An \\
\hline 1 & 11 & 12 & 13 &.. & a1n \\
\hline 2 & 21 & 22 & 23 &.. & a2n \\
\hline .. &.. &.. &.. &.. & $\ldots$ \\
\hline $\mathrm{n}$ & $\mathrm{n} 1$ & $\mathrm{n} 2$ & $\mathrm{n} 3$ & & Ann \\
\hline
\end{tabular}

The aij value is the comparison value of the elements Ai with Aj which states:

1. How far is Ai's importance compared to Aj .'s

2. How big is Ai's contribution to criterion $B$ compared to $\mathrm{Aj}$

3. How many properties of criterion $B$ are found in Ai compared to $\mathrm{Aj}$

If the value of aij is known, then aji = 1/aij. The numerical value used for the above comparison is obtained from the comparison scale made by Saaty, as shown in table 2:

Table 2. Assessment guidelines in pairwise comparisons

\begin{tabular}{lll}
\hline Intensity & Interest Description & Explanation \\
\hline 1 & Both elements are equally important & Two elements have the same effect on the goal \\
\hline 3 & One element is slightly more important than the other & $\begin{array}{l}\text { The rating is slightly in favor of one element com- } \\
\text { pared to its partner }\end{array}$ \\
\hline 5 & One element is more important than the other & $\begin{array}{l}\text { The assessment is very concerned about one ele- } \\
\text { ment over its partner }\end{array}$ \\
\hline 9 & Elements of which one is more important than the other & $\begin{array}{l}\text { Elements of which one is more preferable and } \\
\text { practical dominance is very real compared to its } \\
\text { partner elements }\end{array}$ \\
\hline $2,4,6,8$ & Absolute more important & $\begin{array}{l}\text { One element is shown to be absolutely preferable } \\
\text { to its partner element at the highest level of con- } \\
\text { fidence }\end{array}$ \\
\hline The opposite of the above value: if element i get one of the above values when compared to element j, then element j has the opposite
\end{tabular}
value when compared to element i. (aji=1/aij)

Source: Saaty, 1998: 54

\subsection{Determining Weight}

The weights reflect the results of the comparison (comparison). The weight of each component is expressed by wi, w2,,.., wn. To get the weight wi for each aij assessment, the work is carried out in three stages. 


\section{a. First stage}

Assume that the comparison is based on accurate real measurement results. To compare A1 with A2, benchmarks are taken from the weight of each component. In the ideal case (which is based on exact measurement results), the relationship between the weight wi and the judgment aij is as follows:

aij $=$ wi/wj for $\mathrm{ij}=1,2, \ldots, \mathrm{n}$.

The value of wl/w2 with $\mathrm{ij}=1,2, \ldots, \mathrm{n}$ was obtained from the participants based on the assessment of table 2 above. If the weighting vector of the operating elements A1, A2, ... An is expressed as a vector $w=(w 1, w 2, \ldots, w n)$, then the value of the intensity of importance of the operating elements A1 compared to A2 can be expressed as a ratio of the weights of the elements of Operation A1 to A2 is wl/w2 which is equal to a12 so the original comparison matrix can be shown in table 3 below:

Table 3. Weight comparison matrix

\begin{tabular}{lllll}
\hline & 1 & 2 &.. & An \\
\hline 1 & $1 / \mathrm{w} 1$ & $1 / \mathrm{w} 2$ &.. & $\mathrm{w} 1 / \mathrm{n}$ \\
\hline 2 & $2 / \mathrm{w} 1$ & $2 / \mathrm{w} 2$ &.. & $\mathrm{w} 2 / \mathrm{n}$ \\
\hline.. &.. &.. &.. &.. \\
\hline $\mathrm{N}$ & $\mathrm{n} / \mathrm{w} 1$ & $\mathrm{n} / \mathrm{w} 2$ &.. & $\mathrm{wn} / \mathrm{wn}$ \\
\hline
\end{tabular}

\section{b. Second Stage}

To see how much of an appropriate allowance for deviations is, consider row I of matrix A. The elements of the row are: ail, ai $2, \ldots$, ain. In the ideal case, these values are equal to the ratio: wi/wl, wi/w2, .., wi/wn. If you multiply the first element of the row by wi, the second element by w2, and so on, you get: wi $/$ wl.wl $=$ wi.wi $/ w 2 . w 2=$ wi, .., wi $/$ wj.wj $=$ wi,$\ldots$, wi $/ w n$.wn $=$ wi

The result is a row with identical elements: wi, wi, wi, ..., wi

or wi $=$ mean of (ail. wi, ai2. w2, ..., ain. wn)

So get:

इaijwj $=$ nwi i $=1,2, \ldots . . n$

Which is equivalent to the equation

$\mathrm{AW}=\mathrm{nW}$

\section{c. Third phase}

In the real case, the aij value is not always equal to wi/wj, so the solution to the above equation will be obtained. Henceforth, the value of $\mathrm{n}$ is replaced by a vector, so that:

$$
\mathrm{AW}=\lambda \mathrm{W}, \text { where } \lambda=(\lambda 1, \lambda 2, \lambda 3, \ldots, \lambda \mathrm{n})
$$

Every $\lambda \mathrm{n}$ that satisfies equation (4) is called an eigenvalue, while the vector $\mathrm{W}$ is called an eigenvector. If matrix A is a consistent matrix then all eigenvalues are 0 except one which is equal to $\mathrm{n}$. If matrix $\mathrm{A}$ is an inconsistent matrix, small variations in aij will make $\mathrm{t}$ the largest eigenvalue max remains close to $\mathrm{n}$, and the other eigenvalues are close to zero. The value of max can be found from : AW- $\lambda$ maks.W Or $(\mathrm{A}-\lambda$ maksI $) \mathrm{W}=0$

where $\mathrm{I}$ is the identity matrix and 0 is the zero matrix.

\section{Methods}

The research method to be carried out is to conduct field research to identify the potential of Pulo Makmue BMUG. The method used to determine the identified potential of Ulee Pulo Village is the Analytic Hierarchy Process (AHP) method[26]-[28]. By using this method, the priority scale of several alternatives regarding the potential of Ulee Pulo Village will be found. The complete research steps are shown in Figure 1 below:

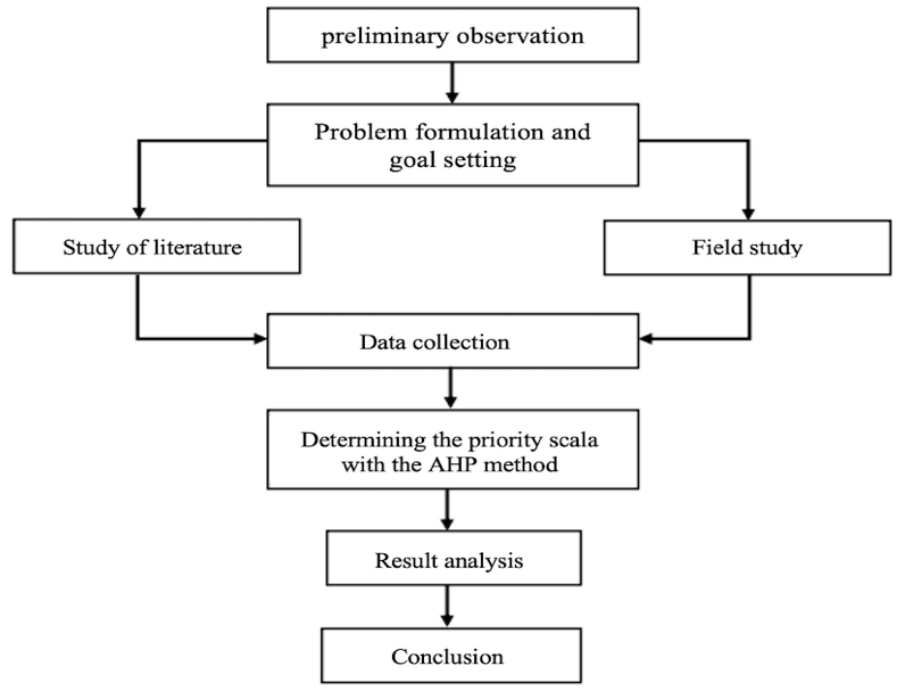

Fig 1. Research Methodology 


\section{Results and Discussion}

\subsection{The Economic Potential of Ulee Pulo Desa Village \\ 4.1.1 Agriculture}

The concept of food security according to Law Number 7 of 1996 is the condition of fulfilling food for households which is reflected in the availability of sufficient food, both in quantity and quality, safe, equitable, and affordable. Ulee Pulo village has very suitable soil conditions for rice fields. Rice is the leading commodity in Ulee Pulo Village, facilities and infrastructure, especially irrigation, are very supportive. Rice from agriculture in Ulee Pulo Village is marketed around North Aceh. In addition to planting rice, the people in Ulee Pulo Village also plant secondary crops, such as corn, beans, cucumbers, chilies, and others. With the potential of Ulee Pulo Village, especially in the agricultural sector, it should be one of the potentials that must be considered, because of adequate infrastructure and the creation of farmer groups (gapoktan) which are expected to increase crop productivity. However, there are several obstacles related to increasing crop productivity in the agricultural sector recently, including:

a. the majority of farmers in Ulee Pulo Village are not land owners, but farm laborers;

b. farmer regeneration is almost non-existent;

c. the number of farm laborers is decreasing every year;

d. distribution of farmers' crops cannot be directly sold to the market but must be through middlemen;

e. the reduction of productive agricultural land in Ulee Pulo Village.

\subsubsection{Fishery}

The fisheries sector plays an important role in creating jobs, providing food, and as a source of foreign exchange for the country. One of the fisheries sub-sectors, namely aquaculture, has an increasingly important role in development in Indonesia. Ulee Pulo Village as a freshwater center area in Aceh has a large potential for freshwater fisheries. This can be an opportunity to open a business in the fisheries sector.

Gampong Ulee Pulo is a center for freshwater fish cultivation in North Aceh Regency, ranging from fish breeding, enlargement to the production of processed fish products. As many as 50 heads of families work as fish cultivators. However, there are obstacles that are felt by fish cultivators in Ulee Pulo Village in running their business, including:

a. Knowledge of sales and marketing management is still lacking;

b. The cost of production and maintenance of ponds increases every year;

c. Farmers' knowledge of technological developments is very low;

\subsubsection{Buy and sell}

Trade is an economic activity that connects producers to consumers. As a distribution activity, trade guarantees the circulation, distribution, and supply of goods through market mechanisms. The large population of Ulee Pulo makes the consumptive level of the population also very high. People try to fulfill their needs and wants. This opens up opportunities for people to become entrepreneurs. A business that provides daily necessities is very necessary so that it becomes a very promising business opportunity. Gampong Ulee Pulo is located 4 kilometers from the city center of North Aceh Regency which is the main route to the city from several villages with high population density. In addition, Gampong Ulee Pulo is an area of the Medan-Banda Aceh highway so that it becomes a strategic area in building village markets.

\subsubsection{Livestock}

Livestock is the activity of breeding and raising livestock to obtain the benefits and results of these activities. Livestock in Ulee Pulo Village is very small compared to other commodities. However, increasing productivity in the livestock sector can be increased with the participation of the government through relevant agencies on how to introduce possible types of livestock for the community in Ulee Pulo Village.

\subsubsection{Community Creative Economy}

According to Soemodiningrat, creative industries that rely on talent, skills, and creativity are the basic elements of every individual. The main elements of the creative industry are creativity, expertise, and talent that have the potential to increase welfare through the offering of intellectual creations. Seeing the large number of human resources and raw materials that can be processed, Ulee Pulo Village has the potential to develop industries in the creative economy sector. The development of the community's creative industry in Ulee Pulo Village is quite developed, as evidenced by the emergence of a cottage industry formed from Acehnese specialties. In addition to food in Ule Pulo Village, other creative industries have also emerged, including the clothing industry, textile industry, and handicraft industry, such as making wallets and bags. One of the obstacles that occur in increasing the productivity of this community-based home-based creative industry is the marketing factor. The difficulty of getting Home Industry Food (PIRT) and even registering with the Food and Drug Supervisory Agency (BPOM) makes this home industry seem to be suspended.

\subsubsection{Transportation Service}

Transportation Services is a business field that provides services for the transportation or transfer of goods and/or people with a certain distance and the capital used. This type of business is one of the most developed business fields today. In this era, most of the Indonesian people are very dependent on the means of transportation. People's dependence on this means of transportation is also a business opportunity. The reason is that there will be no end to the consumers of public transport. In addition, with the development of online shopping activities, freight forwarding services are also a sector that must be developed. This can be a source of income.

\subsection{Determining Alternative Priorities}

To determine alternative priorities in developing the potential of Ulee Pulo Village, the model used is the Analytical Hierarchy Process. Where this model is one model that is suitable for determining the priority of several available alternatives. The steps in determining the priority scale for developing the potential of Ulee Pulo Village are as follows: 


\subsubsection{Setting Goals}

The purpose of using the Analytical Hierarchy Process (AHP) is to identify the potential of villages to develop BUMG Ulee Pulo.

\subsubsection{Determining Criteria}

There are several criteria to identify Gampong Potential to Develop BUMG Ulee Pulo, which are as follows:
a. Long Term Prospects
b. Initial capital
c. Income (Revenue)

\subsubsection{Determining Alternatives}

To identify the potential of the village to develop BUMG Ulee Pulo, there are several alternatives that can be chosen, namely as follows:
a. Fisheries
b. Ricefield
c. Creative Economy
d. Trade
e. Transportation
f. Farmland

\subsubsection{Assessment Criteria}

To identify the potential of gampongs to develop BUMG Ulee Pulo, it was determined by distributing questionnaires to determine the criteria and level of importance of each potential. The number of questionnaires distributed was 30 ex, the number of returned questionnaires was 25 ex. The results of the questionnaire processing can be seen in the priority of each potential criteria desired by the respondents as shown in table 1 below:

Table 1. Criteria Weight

\begin{tabular}{clc}
\hline No & Criteria & Priority of \\
\hline 1 & Long Term Prospect & 1 \\
\hline 2 & Startup Capital & 2 \\
\hline 3 & Income & 3 \\
\hline
\end{tabular}

\subsubsection{Developing Criteria in Pairwise Comparison Matrix}

Based on table 1 above, it can be arranged into a pairwise comparison matrix as in table 2 below:

Table 2. Comparison of Paired Criteria

\begin{tabular}{lccc}
\hline & Long Term Prospect & Startup Capital & Income \\
\hline Long Term Prospect & 1 & 3 & 5 \\
\hline Startup Capital & $1 / 3$ & 1 & 3 \\
\hline Income & $1 / 5$ & $1 / 3$ & 1 \\
\hline
\end{tabular}

\subsubsection{Setting the AHP Hierarchy}

The hierarchical structure of the problem of Gampong Potential to Develop BUMG Ulee Pulo can be arranged in the form of an AHP hierarchy as shown in Figure 1 below:

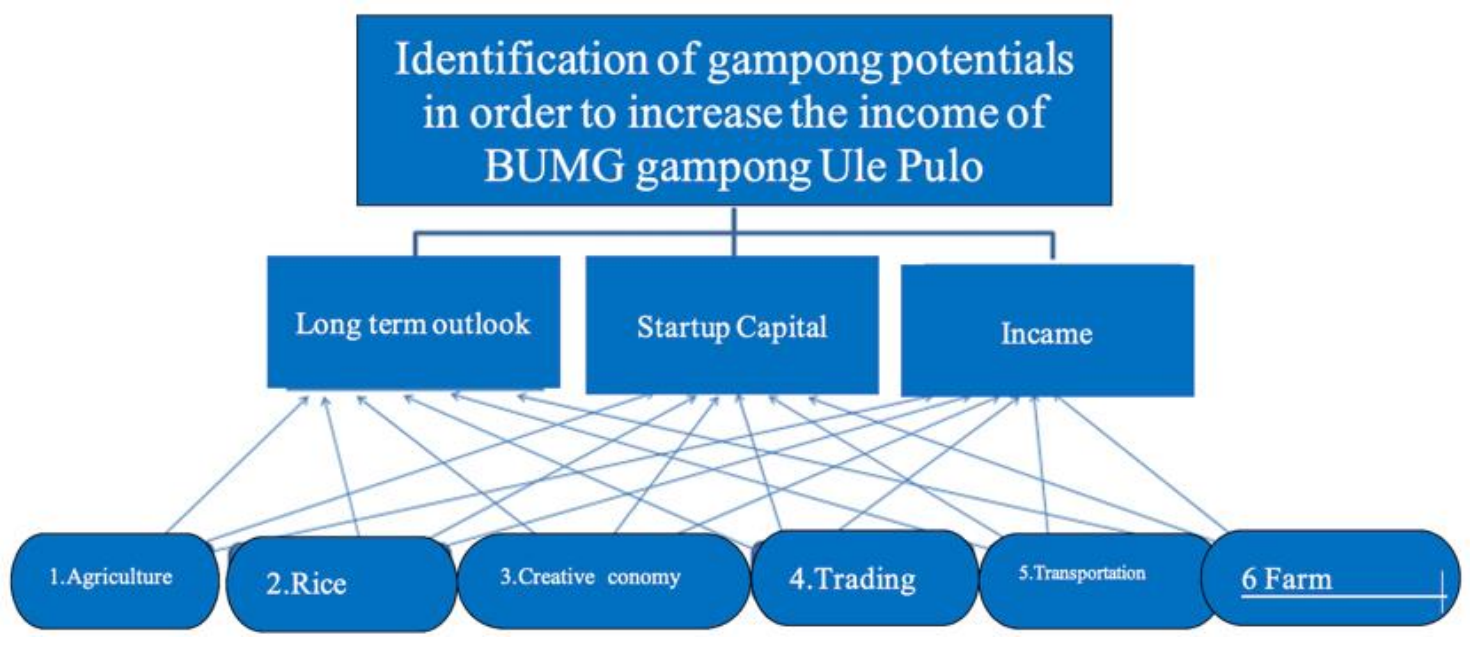

Fig 1. Hierarchical Model of Village Potential for Development of BUMG Ulee Pulo 


\subsubsection{Calculations Using Analytical Hierarchy Process (AHP)}

There are several steps in determining alternative priorities using AHP, which are as follows:a.

a. Calculating the Eigenvector $X$

$$
\mathrm{A}=\left[\begin{array}{ccc}
1 & 3 & 5 \\
0.33 & 1 & 3 \\
0.2 & 0.33 & 1
\end{array}\right] \longrightarrow\left[\begin{array}{lll}
0.65 & 0.69 & 0.56 \\
0.22 & 0.23 & 0.33 \\
0.13 & 0.08 & 0.11
\end{array}\right] \longrightarrow \mathbf{x}=\left[\begin{array}{l}
0.63 \\
0.26 \\
0.11
\end{array}\right]
$$

b. Weight Criteria

a. Long Term Outlook 0.63

b. Working Capital 0.26

c. Revenue 0.11

For the results of the calculation of the potential weight of the village to develop BUMG Ulee Pulo can be seen in Figure 2 below:

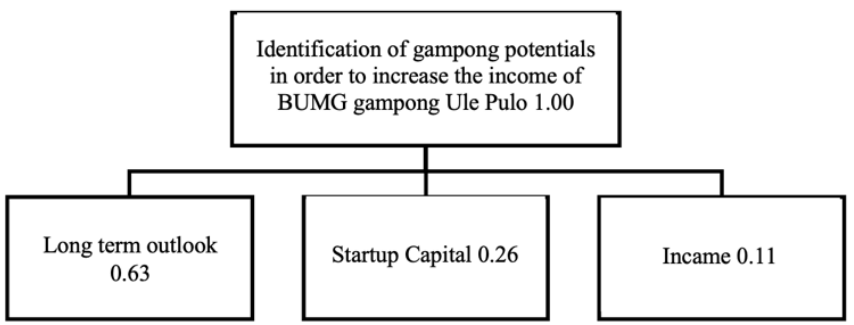

Fig 2. Results of Calculation of Village Potential Weights for the Development of BUMG Ulee Pulo

c. Calculation of Consistency Ratio (CR)

$$
\begin{aligned}
& A=\left[\begin{array}{ccc}
1 & 3 & 5 \\
0.33 & 1 & 3 \\
0.2 & 0.33 & 1
\end{array}\right] \quad X=\left[\begin{array}{c}
0.63 \\
0.26 \\
0.1
\end{array}\right] \quad A X=\left[\begin{array}{l}
1.91 \\
0.77 \\
0.31
\end{array}\right] \\
& \alpha \max \left[\begin{array}{c}
0.63 \\
0.26 \\
0.1
\end{array}\right] \\
& \lambda \max =\left[\left(\frac{1.91}{0.63}\right)+\left(\frac{0.77}{0.26}\right)+\left(\frac{0.31}{0.1}\right)\right] / \mathrm{n} \\
& \lambda \max =\left(\frac{9.09}{3}\right) \\
& \lambda \max =3.03
\end{aligned}
$$

d. Consistency Index Calculation (CI)

$$
\begin{aligned}
& \lambda \max =(\lambda \max -n) /(n-1) \\
& \lambda \max =(3.03-3) /(3-1) \\
& \lambda \max =0.03 / 2 \\
& \lambda \max =0.015
\end{aligned}
$$

e. Calculation of Consistency Ratio (CR)

Calculate the Consistency Ratio (CR) value based on the Random Index (RI) value with table 3 as follows:

Table 3. Value of Random Index (RI)

\begin{tabular}{ccccccccccc}
\hline $\mathrm{N}$ & 1 & 2 & 3 & 4 & 5 & 6 & 7 & 8 & 9 & 10 \\
\hline $\mathrm{RI}$ & 0.00 & 0.00 & 0.58 & 0.90 & 1.12 & 1.24 & 1.32 & 1.41 & 1.45 & 1.49 \\
\hline
\end{tabular}

Based on the above data obtained Consistency Ratio:

$$
\begin{aligned}
\mathrm{CR} & =\mathrm{CI} / \mathrm{RI} \\
& =\mathrm{CI} / 0.58 \\
& =0.015 / 0.58 \\
& =0.026
\end{aligned}
$$

$0.026<0.015$, then the evaluation is consistent. 


\subsubsection{Alternative Ranking}

To determine the ranking of several alternative potential villages to develop BUMG Ulee Pulo are as follows:

a. Alternative Ranking (1): Long-Term Outlook

To determine the ranking of alternative long-term prospects can be seen in table 4 below:

Table 4. Ranking of Alternative Long-Term Prospects

\begin{tabular}{ccccccc}
\hline & Fishery & Rice fields & Creative Economy & Trading & Transportation & farm \\
\hline Fishery & 1 & 2 & $1 / 3$ & $1 / 3$ & 2 & 2 \\
\hline Rice fields & $1 / 2$ & 1 & $1 / 3$ & $1 / 3$ & 2 & 2 \\
\hline Creative Economy & 3 & 3 & 1 & 2 & 3 & 3 \\
\hline Trading & 3 & 3 & $1 / 2$ & 1 & 3 & 3 \\
\hline Transportation & $1 / 2$ & $1 / 2$ & $1 / 3$ & $1 / 3$ & 1 & 2 \\
\hline farm & $1 / 2$ & $1 / 2$ & $1 / 3$ & $1 / 3$ & $1 / 2$ & 1 \\
\hline
\end{tabular}

\begin{tabular}{|c|c|c|c|c|c|}
\hline 1 & 2 & 0.33 & 0.33 & 2 & 2 \\
\hline 0.5 & 1 & 0.33 & 0.33 & 2 & 2 \\
\hline 3 & 3 & 1 & 2 & 3 & 3 \\
\hline 3 & 3 & 0.5 & 1 & 3 & 3 \\
\hline 0.5 & 0.5 & 0.33 & 0.33 & 1 & 2 \\
\hline 0.5 & 0.5 & 0.33 & 0.33 & 0.5 & $1-$ \\
\hline 8.5 & 10 & 2.82 & 4.32 & 11.5 & 13 \\
\hline$[0.12$ & 0.2 & 0.12 & 0.08 & 0.17 & 0.15 \\
\hline 0.06 & 0.1 & 0.12 & 0.08 & 0.17 & 0.15 \\
\hline 0.35 & 0.3 & 0.34 & 0.46 & 0.26 & 0.23 \\
\hline 0.35 & 0.3 & 0.18 & 0.22 & 0.26 & 0.23 \\
\hline 0.06 & 0.05 & 0.12 & 0.08 & 0.09 & 0.15 \\
\hline .06 & 0.05 & 0.12 & 0.08 & 0.05 & 0.0 \\
\hline
\end{tabular}

$X=\left[\begin{array}{l}0.14 \\ 0.11 \\ 0.32 \\ 0.26 \\ 0.09 \\ 0.08\end{array}\right]$

\section{b. Alternative Ranking (2): Business Capital}

To determine the ranking of alternative venture capital can be seen in table 5 below:

Table 5. Ranking of Alternative Business Capital

\begin{tabular}{lcccccc}
\hline & Fishery & Rice fields & Creative Economy & \multicolumn{2}{c}{ Trading } & Transportation \\
\hline Fishery & 1 & $1 / 3$ & $1 / 3$ & 2 & 3 & 2 \\
\hline Rice fields & 3 & 1 & $1 / 3$ & $1 / 3$ & 3 & 2 \\
\hline Creative Economy & 3 & 3 & 1 & 3 & 3 & 3 \\
\hline Trading & $1 / 2$ & 3 & $1 / 3$ & 1 & 3 & 3 \\
\hline Transportation & $1 / 3$ & $1 / 3$ & $1 / 3$ & $1 / 3$ & 1 & $1 / 3$ \\
\hline Farm & $1 / 2$ & $1 / 2$ & $1 / 3$ & $1 / 3$ & 3 & 1 \\
\hline
\end{tabular}

$\mathbf{A}=\left[\begin{array}{cccccc}1 & 0.33 & 0.33 & 2 & 3 & 2 \\ 3 & 1 & 0.33 & 0.33 & 3 & 2 \\ 3 & 3 & 1 & 3 & 3 & 3 \\ 0.5 & 3 & 0.33 & 1 & 3 & 3 \\ 0.33 & 0.33 & 0.33 & 0.33 & 1 & 0.33 \\ 0.5 & 0.5 & 0.33 & 0.33 & 3 & 1\end{array}\right]$




$$
=\left[\begin{array}{rrrrrr}
0.12 & 0.04 & 0.12 & 0.29 & 0.19 & 0.18 \\
0.36 & 0.12 & 0.12 & 0.05 & 0.19 & 0.18 \\
0.36 & 0.37 & 0.4 & 0.42 & 0.19 & 0.26 \\
0.06 & 0.37 & 0.12 & 0.14 & 0.19 & 0.26 \\
0.04 & 0.04 & 0.12 & 0.05 & 0.05 & 0.03 \\
0.06 & 0.06 & 0.12 & 0.05 & 0.19 & 0.09
\end{array}\right]
$$

$X=\left[\begin{array}{c}0.16 \\ 0.17 \\ 0.33 \\ 0.19 \\ 0.06 \\ 0.09\end{array}\right]$

c. Alternative Ranking (3): Income (Income)

To determine the ranking of income alternatives, it can be seen in table 6 below:

Table 6. Ranking of Income Alternatives

\begin{tabular}{lcccccc}
\hline & Fishery & Rice fields & Creative Economy & Trading & Transportation & Farm \\
\hline Fishery & 1 & 2 & $1 / 3$ & $1 / 3$ & 2 & 2 \\
\hline Rice fields & $1 / 2$ & 1 & $1 / 3$ & $1 / 3$ & 2 & 2 \\
\hline Creative Economy & 3 & 3 & 1 & 2 & 3 & 3 \\
\hline Trading & 3 & 3 & $1 / 2$ & 1 & 3 & 3 \\
\hline Transportation & $1 / 2$ & $1 / 2$ & $1 / 3$ & $1 / 3$ & 1 & 2 \\
\hline Farm & $1 / 2$ & $1 / 2$ & $1 / 3$ & $1 / 3$ & $1 / 2$ & 1 \\
\hline
\end{tabular}

$\mathrm{A}=\left[\begin{array}{cccccc}1 & 2 & 0.33 & 0.33 & 2 & 2 \\ 0.5 & 1 & 0.33 & 0.33 & 2 & 2 \\ 3 & 3 & 1 & 2 & 3 & 3 \\ 3 & 3 & 0.5 & 1 & 3 & 3 \\ 0.5 & 0.5 & 0.33 & 0.33 & 1 & 2 \\ 0.5 & 0.5 & 0.33 & 0.33 & 0.5 & 1 \\ 8.5 & 10 & 2.82 & 4.32 & 11.5 & 13\end{array}\right]$

$=\left[\begin{array}{cccccc}0.12 & 0.2 & 0.12 & 0.08 & 0.17 & 0.15 \\ 0.06 & 0.1 & 0.12 & 0.08 & 0.17 & 0.15 \\ 0.35 & 0.3 & 0.34 & 0.46 & 0.26 & 0.23 \\ 0.35 & 0.3 & 0.18 & 0.22 & 0.26 & 0.23 \\ 0.06 & 0.05 & 0.12 & 0.08 & 0.09 & 0.15 \\ 0.06 & 0.05 & 0.12 & 0.08 & 0.05 & 0.09 \\ 1 & 1 & 1 & 1 & 1 & 1\end{array}\right]$

$X=\left[\begin{array}{l}0.14 \\ 0.11 \\ 0.32 \\ 0.26 \\ 0.09 \\ 0.08\end{array}\right]$

The results of the calculation of several alternative potential villages to develop BUMG Ulee Pulo can be seen in Figure 3 below: 


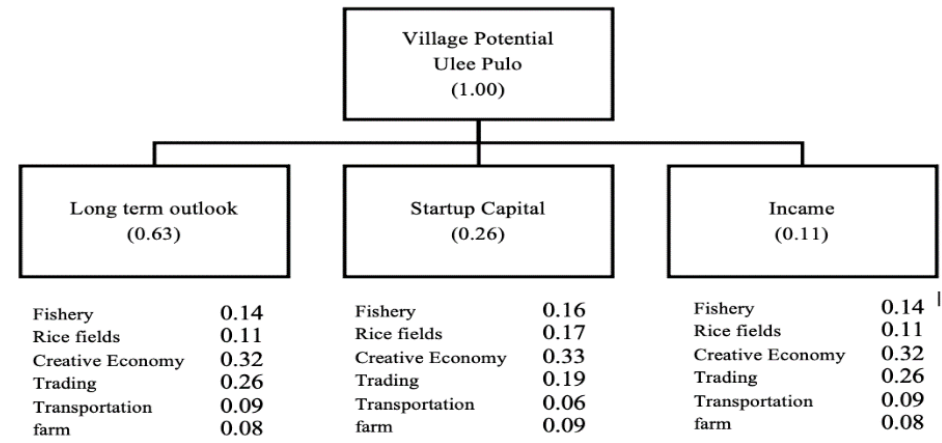

Fig 3. Calculation of several alternative potential villages for development BUMG Ulee Pulo

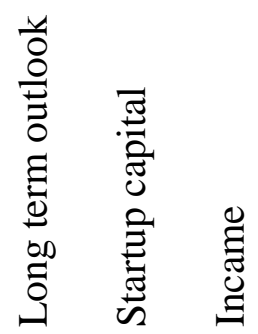

Fishery

Rice fields Creative

Economy

Trading

Transportation

farm $\left[\begin{array}{lll}0.14 & 0.16 & 0.14\end{array}\right.$

$\begin{array}{lll}0.11 & 0.17 & 0.11\end{array}$

$\begin{array}{lll}0.32 & 0.33 & 0.32\end{array}$

$\begin{array}{lll}0.26 & 0.19 & 0.26\end{array}$

$\begin{array}{lll}0.09 & 0.06 & 0.09\end{array}$

$\begin{array}{lll}0.08 & 0.09 & 0.08\end{array}$

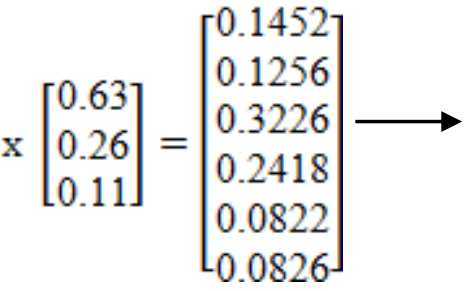

The highest

weight is the

chosen alterna-

tive

Based on the results of calculations obtained using the Analytical Hierarchy Process (AHP) method, the alternative chosen is the potential of villages in the creative economy sector with a description that can be seen in table 7 below:

Table 7. Calculation results of several alternative potential villages to develop BUMG Ulee Pulo

\begin{tabular}{cccc}
\hline No & Alternative & \multicolumn{2}{c}{ Weight Priority to } \\
\hline 1 & Fishery & 0.1452 & 3 \\
\hline 2 & Rice fields & 0.1256 & 4 \\
\hline 3 & Creative Economy & 0.3226 & 1 \\
\hline 4 & Trading & 0.2418 & 2 \\
\hline 5 & Transportation & 0.0822 & 6 \\
\hline 6 & farm & 0.0826 & 5 \\
\hline
\end{tabular}

\section{Conclusion}

Based on the identification of the potential for increasing the business scale of BUMG Pulo Makmue with the AHP method, the following conclusions can be drawn:

1. Gampong Pulo Makmue has several economic potentials. These include agriculture, fisheries, trade, animal husbandry, creative economy, and transportation services. To determine alternative priorities in developing the potential of Ulee Pulo Village in the context of developing Ulee Pulo BUMG, it is determined by distributing questionnaires to determine the criteria and level of importance of each potential. The criteria assessed are long-term prospects, working capital, and income.

2. Based on the results of the analysis of data testing, it can be concluded that the AHP algorithm can be used to assist in making decisions regarding the determination of economic potential to develop BUMG Ulee Pulo. The results of the analysis show that the best business potentials based on the hierarchy of business potential are: (1) Creative Economy (2) Trade (3) Fisheries (4) Rice Fields (5) Livestock (6) Transportation.

\section{Acknowledgement}

We would like to thank all parties involved in this research. We would also like to thank the institute of research and community service (LPPM) Universitas Malikussaleh, for the opportunity given to the research team with the 2021 research fund under the Lecturer scheme from Universitas Malikussaleh.

\section{References}

[1] V. Wineka Nirmala, D. Harjadi, and R. Awaluddin, "Sales Forecasting by Using Exponential Smoothing Method and Trend Method to Optimize Product Sales in PT. Zamrud Bumi Indonesia During the Covid-19 Pandemic," Int. J. Eng. Sci. Inf. Technol., vol. 1, no. 4, 2021, doi: 10.52088/ijesty.v1i4.169.

[2] M. Andriani, H. Irawan, and N. Rizqa Asyura, "Improving Quality Using The Kano Model in Overcoming Competition in The 
Service Industry,” Int. J. Eng. Sci. Inf. Technol., vol. 1, no. 4, 2021, doi: 10.52088/ijesty.v1i4.145.

[3] X. Chen, W. Xie, and H. Li, "The spatial evolution process, characteristics and driving factors of traditional villages from the perspective of the cultural ecosystem: A case study of Chengkan Village," Habitat Int., vol. 104, p. 102250, 2020, doi: https://doi.org/10.1016/j.habitatint.2020.102250.

[4] J. He, X. Shi, and Y. Fu, "Identifying vegetation restoration effectiveness and driving factors on different micro-topographic types of hilly Loess Plateau: From the perspective of ecological resilience," J. Environ. Manage., vol. 289, p. 112562, 2021, doi: https://doi.org/10.1016/j.jenvman.2021.112562.

[5] R. J. Ehwi and D. A. Mawuli, “'Landguardism' in Ghana: Examining public perceptions about the driving factors," Land use policy, vol. 109, p. 105630, 2021, doi: https://doi.org/10.1016/j.landusepol.2021.105630.

[6] C. Cheng et al., "Cropland use sustainability in Cheng-Yu Urban Agglomeration, China: Evaluation framework, driving factors and development paths," J. Clean. Prod., vol. 256, p. 120692, 2020, doi: https://doi.org/10.1016/j.jclepro.2020.120692.

[7] C. Wang, L. Ma, Y. Zhang, N. Chen, and W. Wang, "Spatiotemporal dynamics of wetlands and their driving factors based on PLSSEM: A case study in Wuhan," Sci. Total Environ., p. 151310, 2021, doi: https://doi.org/10.1016/j.scitotenv.2021.151310.

[8] Y. Li, L. Wang, G. Liu, and S. Cheng, "Rural household food waste characteristics and driving factors in China," Resour. Conserv. Recycl., vol. 164, p. 105209, 2021, doi: https://doi.org/10.1016/j.resconrec.2020.105209.

[9] L. Shi and Y. Wang, "Evolution characteristics and driving factors of negative decoupled rural residential land and resident population in the Yellow River Basin," Land use policy, vol. 109, p. 105685, 2021, doi: https://doi.org/10.1016/j.landusepol.2021.105685.

[10] S. Jalalul Akbar, M. Maizuar, K. Yusuf, and J. Arfiandi, "Monitoring the Dynamic Behavior of PCI Bridges Using Short Period Seismograph and CSI Bridge Modeling," Int. J. Eng. Sci. Inf. Technol., vol. 1, no. 4, 2021, doi: 10.52088/ijesty.v1i4.168.

[11] S. Ali Rafsanjani, F. E. Rooslan Santosa, and R. Durrotun Nasihien, "Analysis of Planning for Clean Water Needs at Grand Sagara West Surabaya Hotel With the Green Buillding Concept," Int. J. Eng. Sci. Inf. Technol., vol. 1, no. 2, 2021, doi: 10.52088/ijesty.v1i2.55.

[12] V. Pandey, H. K. Nagarajan, and D. Kumar, "Impact of Gendered Participation in market-linked value-chains on Economic Outcomes: Evidence from India,” Food Policy, vol. 104, p. 102142, 2021, doi: https://doi.org/10.1016/j.foodpol.2021.102142.

[13] S. González-García et al., "Embedding environmental, economic and social indicators in the evaluation of the sustainability of the municipalities of Galicia (northwest of Spain)," J. Clean. Prod., vol. 234, pp. 27-42, 2019, doi: https://doi.org/10.1016/j.jclepro.2019.06.158.

[14] S. Rozelle and R. N. Boisvert, "Control in a dynamic village economy: The reforms and unbalanced development in China's rural economy," J. Dev. Econ., vol. 46, no. 2, pp. 233-252, 1995, doi: https://doi.org/10.1016/0304-3878(94)00060-P.

[15] M. Nurtanto, S. Nurhaji, D. Widjanarko, M. B. R. Wijaya, and H. Sofyan, "Comparison of Scientific Literacy in Engine Tune-up Competencies through Guided Problem-Based Learning and Non-Integrated Problem-Based Learning in Vocational Education," in Journal of Physics: Conference Series, 2018, doi: 10.1088/1742-6596/1114/1/012038.

[16] M. Ikhsan and R. Rinaldy, "Estimated Flood Discharge in Downstream Krueng Meureubo of Pasi Pinang Section West Aceh Regency," Int. J. Eng. Sci. Inf. Technol., vol. 1, no. 1, 2021, doi: 10.52088/ijesty.v1i1.41.

[17] L. Putterman, "On the past and future of china's township and village-owned enterprises," World Dev., vol. 25, no. 10, pp. 16391655, 1997, doi: https://doi.org/10.1016/S0305-750X(97)00060-0.

[18] W. Han, Y. Wei, J. Cai, Y. Yu, "Rural nonfarm sector and rural residents' income research in China. An empirical study on the township and village enterprises aft er ownership reform (2000-2013)," J. Rural Stud., vol. 82, pp. 161-175, 2021, doi: https://doi.org/10.1016/j.jrurstud.2021.01.001.

[19] B. Arifin et al., "Village fund, village-owned-enterprises, and employment: Evidence from Indonesia," J. Rural Stud., vol. 79, pp. 382-394, 2020, doi: https://doi.org/10.1016/j.jrurstud.2020.08.052.

[20] H. A. Dahlan and N. Abdullah, "Comparison and Challenges in the Implementation of Halal Food Laws in Malaysia, the Netherlands and United States of America," J. Undang. dan Masy., 2017, doi: 10.17576/juum-2017-2101-06.

[21] C. Hendratmoko, B. Istiyanto, I. Ayu, and K. Rachmawati, "Development of Empowerment Models for Fish Processors to Increase Income (Case Study on Fish Processors in Cilacap Regency)," J. Paradig., vol. 12, no. 02, pp. 158-178, 2015.

[22] C. Hendratmoko, B. Istiyanto, I. Ayu, and K. Rachmawati, "Pengembangan Model Pemberdayaan Bagi Pengolah Ikan Guna Meningkatkan Pendapatan ( Studi Kasus Pada Pengolah Ikan Di Kabupaten Cilacap ),” J. Paradig., vol. 12, no. 02, pp. 158-178, 2015.

[23] K. Pelzer et al., "Penerapan value Engineering(Ve)Sebagai Pemilihan Alternatif Pembuatan Kantong Tas Belanja Wanita Dengan Konsep Green Product," Solid State Ionics, vol. 2, no. 1, pp. 1-10, 2017.

[24] A. K. Bhardwaj, R. Chauhan, R. Kumar, M. Sethi, and A. Rana, "Experimental investigation of an indirect solar dryer integrated with phase change material for drying valeriana jatamansi (medicinal herb)," Case Stud. Therm. Eng., vol. 10, no. March, pp. 302314, 2017, doi: 10.1016/j.csite.2017.07.009.

[25] Hartono, O. S. Sitompul, E. B. Nababan, Tulus, D. Abdullah, and A. S. Ahmar, "A new diversity technique for imbalance learning ensembles," Int. J. Eng. Technol., 2018, doi: 10.14419/ijet.v7i2.11251.

[26] K. He, L. Pei, X. Lu, J. Chen, and Z. Wu, "Research and Application of Critical Failure Paths Identification Method for Dam Risk Analysis," Math. Probl. Eng., vol. 2020, 2020, doi: 10.1155/2020/4103804.

[27] R. Hidayat, A. Arendra, and S. Akhmad, "Bread Fermentation Machine Development Using Value Engineering (Ve) Approach," Spektrum Ind., vol. 12, no. 1, p. 1, 2014, doi: 10.12928/si.v12i1.1645.

[28] T. L. Saaty and E. Rokou, "How to prioritize inventions," World Pat. Inf., vol. 48, pp. 78-95, 2017, doi: https://doi.org/10.1016/j.wpi.2017.02.003. 